\section{Japanese universities}

\section{Private sector under new stress}

Tokyo

JAPAN's private universities are making plans to get rid of their reputation for profligacy and mismanagement by voluntarily opening their account books to the public. Their poor image has recently cost them dear - three years of cuts in government subsidies have pushed more than half of them into debt and are forcing them to cut back on facilities and scholarships.

At present, Japanese law does not require private universities publicly to declare the source of their income or how it is spent, and much of their financial management has been veiled in secrecy. What has become visible has often been the result of a scandal: universities have faked reports of their expenses in order to receive larger subsidies, have taken huge "donations" to bend the admission rules for substandard students and have paid excessive salaries to directors and professors. Ugly internal feuds have also sometimes broke out: a short while ago, one board director was stabbed to death in a factional squabble over university management. Most of the scandals have been restricted to the smaller schools but even the leading universities have not been immune; one of the bigger medical schools is at present under fire for bending entry requirements.

Now, the Federation of Private University Associations, to which all but 4 per cent of the private universities belong, is preparing guidelines for the public voluntary announcement of financial reports. It is hoped that greater openness will give the universities the public support they need to halt the steady cuts in the government subsidies.

In the 1982 fiscal year, subsidies were frozen, in 1983 they were cut by 2.3 per cent and in 1984 by another 12 per cent. Less than 20 per cent of universities' expenses are now met by the government; a few years ago it was 30 per cent and the original plan was to finance 50 per cent of their expenses.

The result is that college deficits have hit new highs. The 82 members of the Japan League of Private Universities, including such important universities as Keio and Waseda in Tokyo and Dooshisha in Kyoto, have run up cumulative deficits that passed the 100,000 million yen (US\$416 million) mark at the end of the last fiscal year. With income not covering expenditure in 45 universities, cuts are being made in facilities and scholarships.

The government is already considering another cut next year, or at best a one per cent increase which will not even match inflation. There is little doubt that government officials, faced with Finance Ministry demands for further austerities, have taken advantage of criticisms of high salary levels in the private universities to single them out for cuts. But at the same time, their policy makes little sense in the light of the present demographic situation and calls for increases in the number of researchers for Japan's "high-tech revolution".

As the children of the post-war baby boom reach university age, a massive increase in the number of university students is expected: the Ministry of Education is expecting an additional 86,000 enrolments a year in the early 1990 s. But the boom will be short-lived - it will last only from 1986 to 1992 , after which the population of 18-year-olds will fall dramatically. At present, 80 per cent of students go to private universities and the Ministry of Education wants to keep this constant; 80 per cent of the bulge is thus to be taken up by private universities. But far from preparing for the rush, private universities are now actually cutting back.

The only other way to pay for new facilities is to increase tuition fees, but there are signs that they are already close to what the market can bear. The average Tokyo family already spends 64,000 yen $(\$ 267)$ a month on education. For those with a child

\section{Washington}

DR Walter Gilbert, who gave up his faculty position at Harvard University to run the biotechnology company he founded, has now resigned as chairman of the company, Biogen. His action came after months of rumours about friction between Gilbert and members of the board, particularly those members with business experience.

Gilbert will continue to serve on Biogen's science advisory and supervisory



Dr Walter Gilbert with new chief executive

boards. A new chairman is expected to be chosen in February.

Biogen recently fired 16 per cent of its staff, a major cutback that some industry analysts interpreted at the time as a message to Gilbert of the board's dissatisfaction. Spokesmen for the company maintain, however, that the lay-offs were Mark Skaletsky

at a private university and another at a private high school, average expenditure on schooling comes close to 40 per cent of total living costs.

What seems likely in the near future is that private universities will simply take on more students without a substantial increase in staff or facilities. This will inevitably lead to a decline in standards. Private schools on average already spend per student only a quarter of what a state university can afford, the studentprofessor ratio is three times as high and classroom space per student one-third that in a state university. Few private universities can match state university standards.

These are problems that will clearly need urgent discussion in Prime Minister Yasuhiro Nakasone's Educational Reform Council, which has already begun its deliberations (see Nature 309, 739; 1984). Nakasone has himself stressed the need for increasing diversity in higher education, which he believes can be provided by the private sector. But the council has so far concerned itself largely with primary and secondary education and by the time it delivers its final report in 1986 the student boom will have begun.

Alun Anderson

\title{
Gilbert resigns from Biogen
}

part of a general "house-cleaning" designed to increase efficiency and check the company's overly rapid growth. Genex, another biotechnology company that has been growing very rapidly, announced a similar retrenchment this month.

Even with the lay-offs, Biogen will have grown 20 per cent this year, and further staff increases are expected in 1985. The company has a strong financial footing, with enough amassed capital to continue current programmes for several years before marketing its first products, according to Scott King, an analyst for Montgomery Securities. Although the company was able to raise only half of the $\$ 60$ million it had sought for a limited research and development partnership, it was able to put up the remaining $\$ 30$ million from internal funds.

Zsolt Harsanyi, vice-president of $\mathbf{E}$. F. Hutton, says that some of the company's rapid growth may be attributable to the phenomenon, familiar on Wall Street, of "presentation of growth" - the desire of a company going public to give the appearance of rapid expansion.

The explanation may apply to Genex as well, although Genex seems to have run into more serious financial straits. A Genex spokesperson said that a number of costly design changes had been necessary in its phenylalanine plant, at present under construction in Paducah, Kentucky. Phenylalanine is the starting material for aspartame, the soft-drink sweetener. The layoffs are expected to save Genex more than $\$ 1$ million a year. 